\title{
Orientations and origins: a symbolic dimension to the long house in Neolithic Europe
}

\author{
RICHARD BRADLEY*
}

The long houses of the Linear Pottery Culture and its immediate successors are usually interpreted in functional terms, but they have certain anomalous features. This paper considers the processes by which they were built, lengthened, abandoned and replaced and suggests that they may have charted the development of the households who lived inside them. The buildings in Linear Pottery settlements were generally orientated towards the areas of the origin of the communities who lived there.

Key-words; long houses, long barrows, Linear Pottery Culture, ancestors

\section{Long houses and long mounds}

The similarities between long barrows and long houses were discussed by Gordon Childe over 50 years ago (Childe 1949). Since his paper was published, the same observation has been considered from many different perspectives, yet the reasons for this connection are hard to grasp. This article contends that much of the difficulty is created, not by problems of chronology, but by the expectations that archaeologists have brought to the discussion. Long mounds are connected with the dead and contribute to the study of mortuary practices, whilst long houses are the dwellings of the living and are investigated in terms of subsistence and settlement. These two approaches to the Neolithic period fail to articulate with one another.

Childe was concerned with evidence from northern Europe but recently similar observations have been made in France. In each case it seems as if timber long houses were replaced by earthen mounds of similar proportions. There is little agreement on the timing of this development in the region studied by Childe, where the houses and mortuary mounds occur on different sites and may be separated in time by a century or more (Midgley 1992: 463-4), but at Balloy, Seine-et-Marne, the positions of individual houses were overlain by earthworks that shared the sizes and orientations of those buildings (Mordant 1997). Even though some time may have elapsed between these different kinds of structure, it is obvious that the people responsi- ble for the long barrows had a precise understanding of the layout of the older settlement.

Because both groups of structures at Balloy follow a similar ground plan, it has been tempting to interpret these earthworks as the houses of the dead, but that does not explain why the form of domestic buildings was so well suited to this kind of symbolic elaboration. Did the houses conform to a wider conceptual scheme, as we so often find in the ethnographic literature (Carsten \& Hugh-Jones 1995; Birdwell-Pheasant \& Lawrence-Zúniga 1999)? In this paper I shall consider both the features that they share with long barrows: their length and orientation.

\section{The life cycle of long houses}

The long houses of the Linear Pottery Culture are distributed across a wide area and were built to a strikingly uniform design which seems to have persisted for more than 500 years (Whittle 1996: chapter 6). Did the organization of these houses have a special significance?

In fact these buildings exhibit a number of recurrent features which have still to be explained (Modderman 1988; Coudart 1998). Their length itself poses problems. It has always been accepted that in northwest Europe (the area considered in this article) these buildings may have had as many as three distinct segments; this is not so obvious in areas further to the east and southeast. It is not clear that these components were constructed simultaneously. The central section occurs in every case and

\footnotetext{
* Department of Archaeology, Whiteknights, PO Box 218, Reading kG6 6AA, England. R.J.Bradley@reading,ac.uk Received 16 May 2000, accepted 18 July 2000, revised 17 October 2000

ANTIQUITY 75 (2001): 50-56
} 

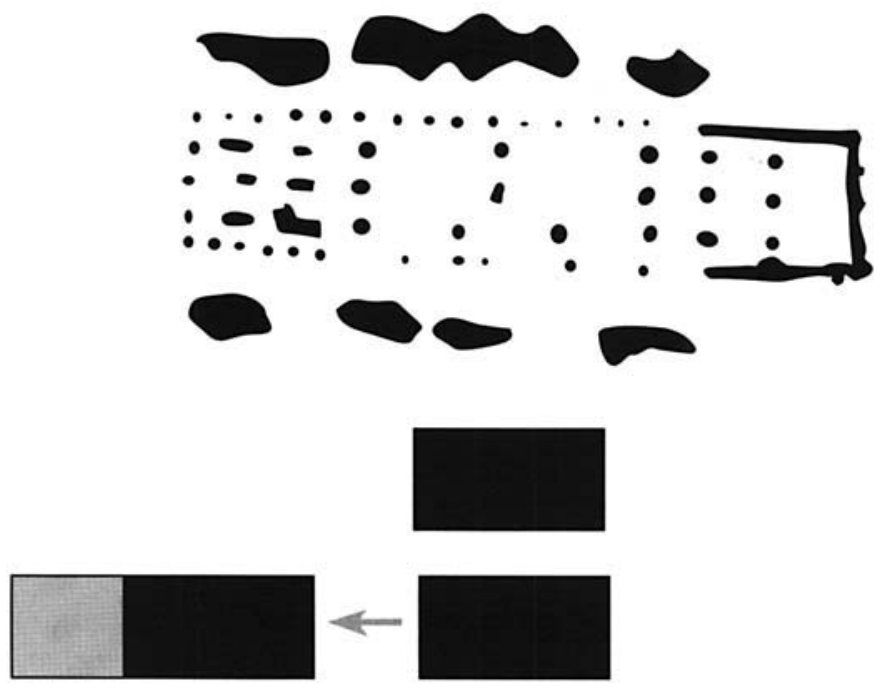

FIGURE 1. Outline plan of a Linear Pottery Culture long house at Geleen, Netherlands (after Waterbolk 1959) and block diagrams summarizing the tripartite organization of space inside such buildings. The diagrams summarize the logical relationships between the central section and those towards the north and south. Bold arrows show sequences that are documented archaeologically. The faint arrows indicate other sequences of development that are possible but conjectural.
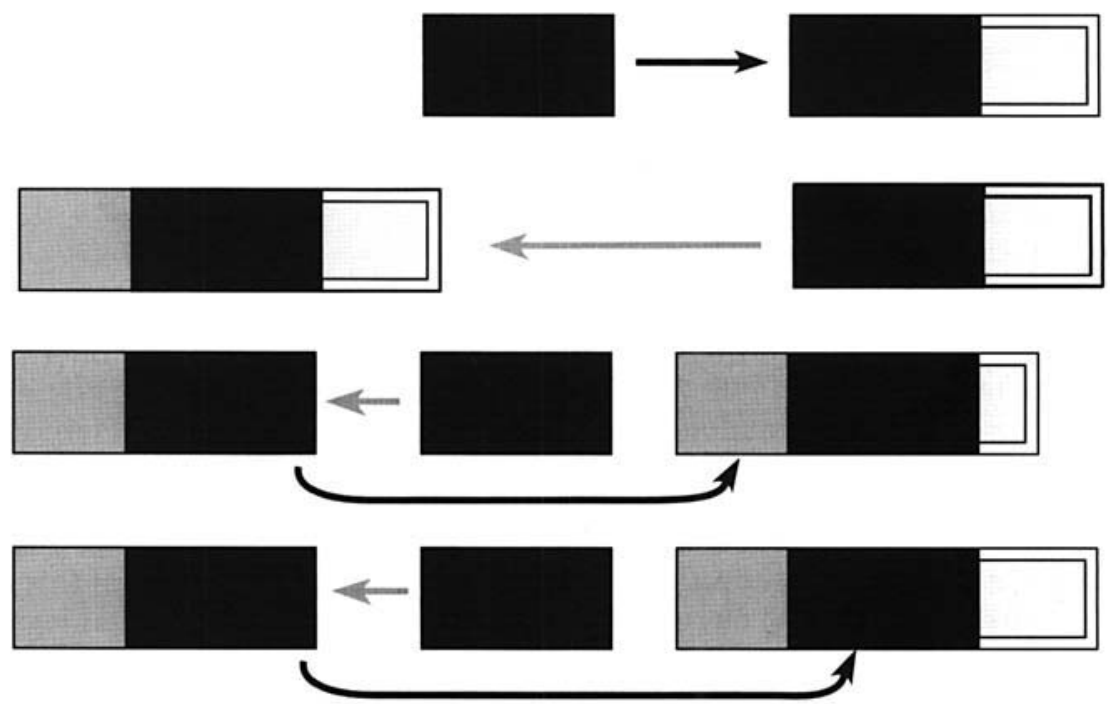

can also be found on its own. At one end it may be supplemented by a massive structure that is commonly identified as a granary, and at the opposite end there may be a further compartment which was often set within a continuous foundation trench that may have held planks (Coudart 1998: chapter 2). The entire building could be flanked by borrow pits which provided raw material for plastering the walls.

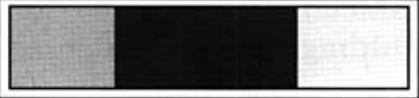

MID SECTION 

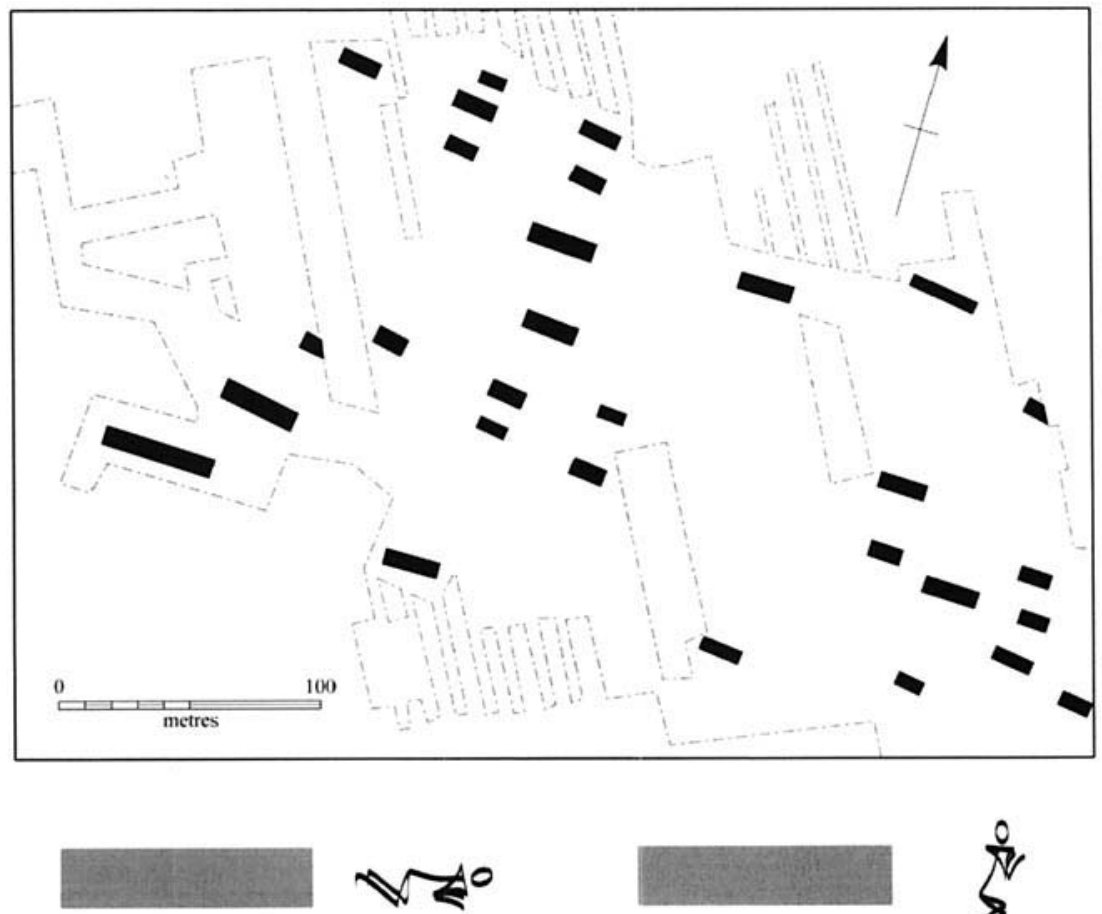
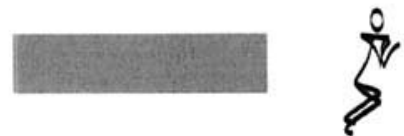

FIGURE 2 (above). Outline plan of the excavated long house settlement at Cuiry-les-

Chaudardes (after Coudart 1998), illustrating the roughly even spacing and alignment of buildings erected at different times in the life of the settlement. The lower drawing summarizes the relationship between the alignment of long houses in northwest Europe and the orientation of nearby burials (after Mattheusser 1991). tion can be incorrectly aligned, leading to the suggestion that it could have been added at a later stage (Coudart 1998: 74). FIGURE 1 summarizes the logical relations that are possible between the three components of the long house and distinguishes between sequences that can be demonstrated by field archaeology and those that are entirely conjectural. One point is well established: in normal circumstances the provision of the trench-built 'northern' element brought any expansion in that direction to an end. Although that compartment is not always the same size, it is rare to find houses in which the final segment of the building was replaced (Coudart 1998: 53-5).

There are links between the interior and exterior. The internal area was clearly subdivided and the separate elements were built in different techniques. The same emphasis on segmentation extends to the area outside these buildings. Not only was the northern end of the longest structures built in a different style from the other components, the internal organization of space was often mirrored by the positioning of external borrow pits (Coudart 1998: 32-3). Sometimes these followed the full extent of the side walls but often they were interrupted by causeways. The importance of these divisions has rarely been discussed, and yet they mirror the internal structure of the buildings. Simonin (1997) suggests that they reflected the positions of windows in the houses, but a purely functional interpretation may be insufficient as these pits can also be associated with child burials (Veit 1996).

Discussions of this evidence have followed a strictly practical logic. Modderman has compared these buildings with later long houses, in which each section of the structure served a different purpose (1988: 96). The southern section of the Neolithic house has been interpreted as a granary and the northern section as a byre. This is hardly likely as these buildings were apparently entered by a door at the southern end, whereas the byres in later long houses were usually approached through openings in the side walls (Fokkens \& Roymans 1991). It seems improbable that livestock would have crossed the living area to enter and leave these buildings. In any event this interpretation of Neolithic long houses receives little support from phosphate analysis (Stäuble \& Lüning 1999).

Hunter-Anderson (1977) has pointed out that it is easier to add sections to a rectilinear structure than it would be in the case of circular buildings . Perhaps the extra compartments were 
created as the household increased in size or as more generations came to live together. This process is documented in the ethnographic record (Carsten \& Hugh-Jones 1995) and a similar approach has been applied to Iron Age houses in the Netherlands (Gerittson 1999). Shorter structures are widely distributed in Neolithic Europe, but Coudart (1998: 48-9) observes that they are more frequent towards the end of the occupation of individual sites. This suggests that in some cases the process of lengthening the long house had still to run its course when the entire settlement was relocated.

In nearly all the settlements of the Linear Pottery Culture and its immediate successors, individual long houses were replaced in different positions from the original buildings (Lüning 1982). The abandoned structures and their successors followed the same alignment and often they adhered to the same spacing across the settled area (FIGURE 2). Where excavated evidence is available, there seems to be little sign that such structures had been repaired or that materials were retrieved when houses were abandoned. Perhaps the positions of older buildings were respected whilst their structure decayed.

This suggests a rather striking process by which individual houses might be extended, abandoned and relocated at different stages in their structural development. Although they were composed of distinct segments, the creation of a closed 'northern' section walled with planks almost invariably brought that process to an end. The distinctive structure of these buildings would have made that sequence of development apparent to an outside observer.

How is that to be explained? Perhaps the most likely explanation is that such buildings were replaced on the death of one of the occupants, just as in other parts of Europe houses seem to have been burnt down with their contents inside them (Stevanovic 1997). The most complex long houses might have been those that developed across a whole generation, in which case the secluded compartment at the northern end could have taken on a special significance. It seems to have been the last to be built before these houses were abandoned and might have been used as an ancestral shrine or even as a mortuary. Once it had been built there is nothing suggest any further elaboration of the structure.

There is some evidence to support a link between the development of the house and the importance of the dead. Child burials are found with individual long houses (Veit 1996) and Whittle has suggested an association between these deposits and the regeneration of the social group (1996: 167). Burials of adults can be found in cemeteries located some distance from the settled area (Veit 1996). In this case the bodies face in the same direction as the doors of the long houses (FIGURE 2; Mattheusser 1991; Whittle 1996: 169). Perhaps that is one reason why the earliest mortuary mounds were modelled on the dwellings used in life.

\section{The alignment of long houses}

The orientation of the long house also seemed to be governed by practical considerations. Marshall (1981) suggested that it was determined by local wind directions (cf. Mattheusser 1991: 35-7). His analysis was based on an unrepresentative sample, but in any case it is doubtful whether buildings in small clearings would have been as vulnerable to wind pressure as their later counterparts which were constructed in a more open landscape. Coudart's study (1998: 8890) of a larger sample of Neolithic long houses could not identify any relationship between the orientation of these buildings and the directions of the prevailing winds (FIGURES $3 \& 4$ ).

The most obvious characteristics of the Linear Pottery Culture are its geographical extent and the rapidity with which it spread across central and western Europe. The uniform character of its settlements and artefacts suggests that people in these regions saw themselves as a single community. Lüning et al. (1989) have suggested a broad pattern of colonization extending from central Europe towards the northwest, with further areas of settlement towards the west and northeast (FIGURE 4).

It is usually supposed that the long houses of this period follow a north-south axis, but in fact their orientations are much more varied (Mattheusser 1991: 17-25). Far from following the directions of the prevailing winds, the orientations of those buildings seem to conform to a much more basic alignment. They appear to reflect the sequence and direction of Linear Pottery Culture colonization. Thus they face approximately north-south in central Europe and are deflected towards the west and northwest towards the limit of expansion (FIGURE 4). The range of variation is sufficiently striking to suggest this was a deliberate choice. In every instance the position of the door is to- 

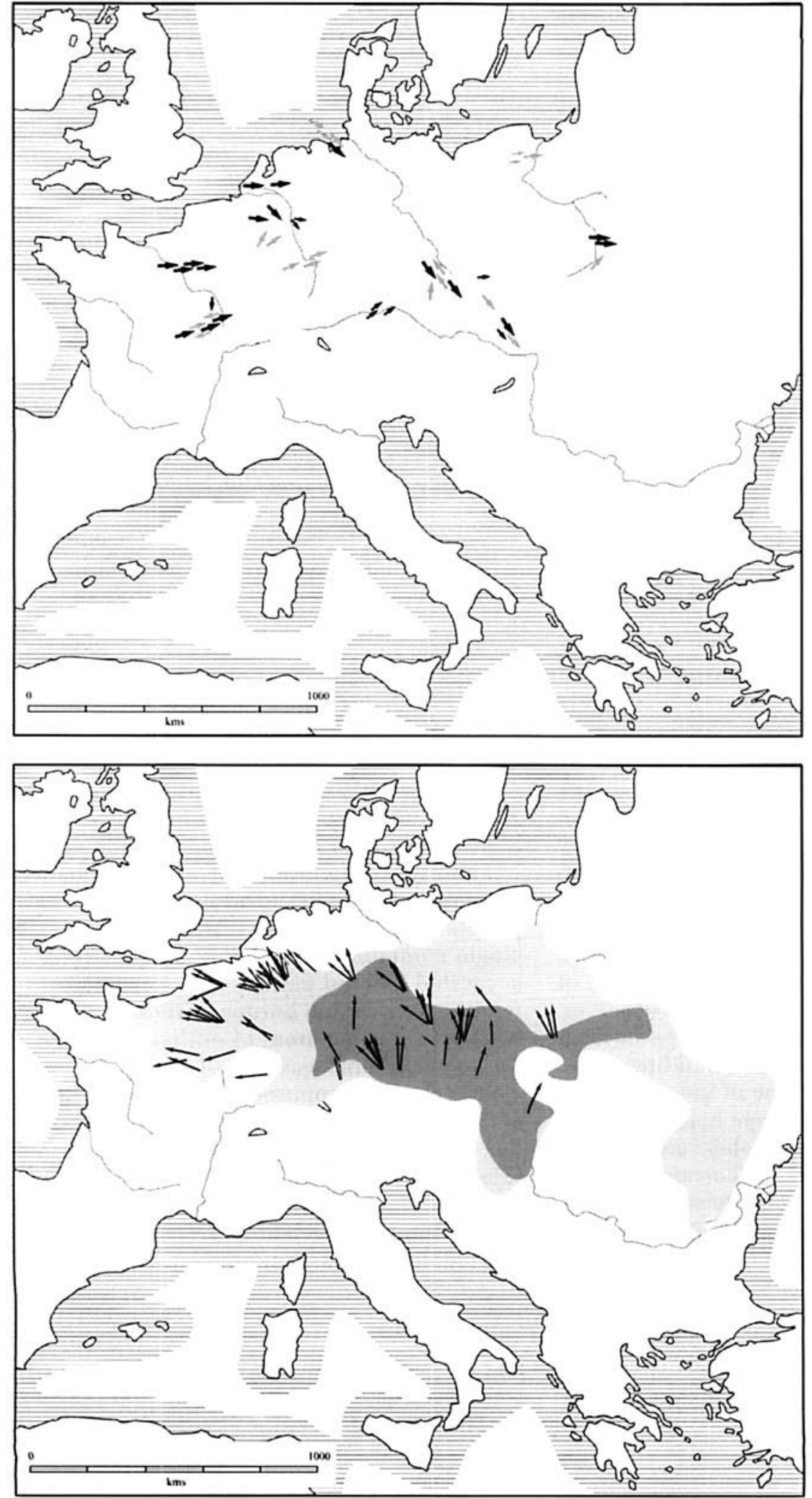

FiguRE 3. Prevailing wind directions in the regions of Europe with Neolithic long houses (after Coudart 1998). The bold arrows show the main wind directions in summer and the fainter arrow those in winter.

FIGURE 4. The chronological extension of the Linear Pottery Culture (after Lüning et al. 1989) compared with the orientations of Neolithic long houses (after Kind 1989 and Coudart 1998). The denser shading indicates the earlier phases of Linear Pottery settlement and the lighter shading traces its subsequent expansion. 


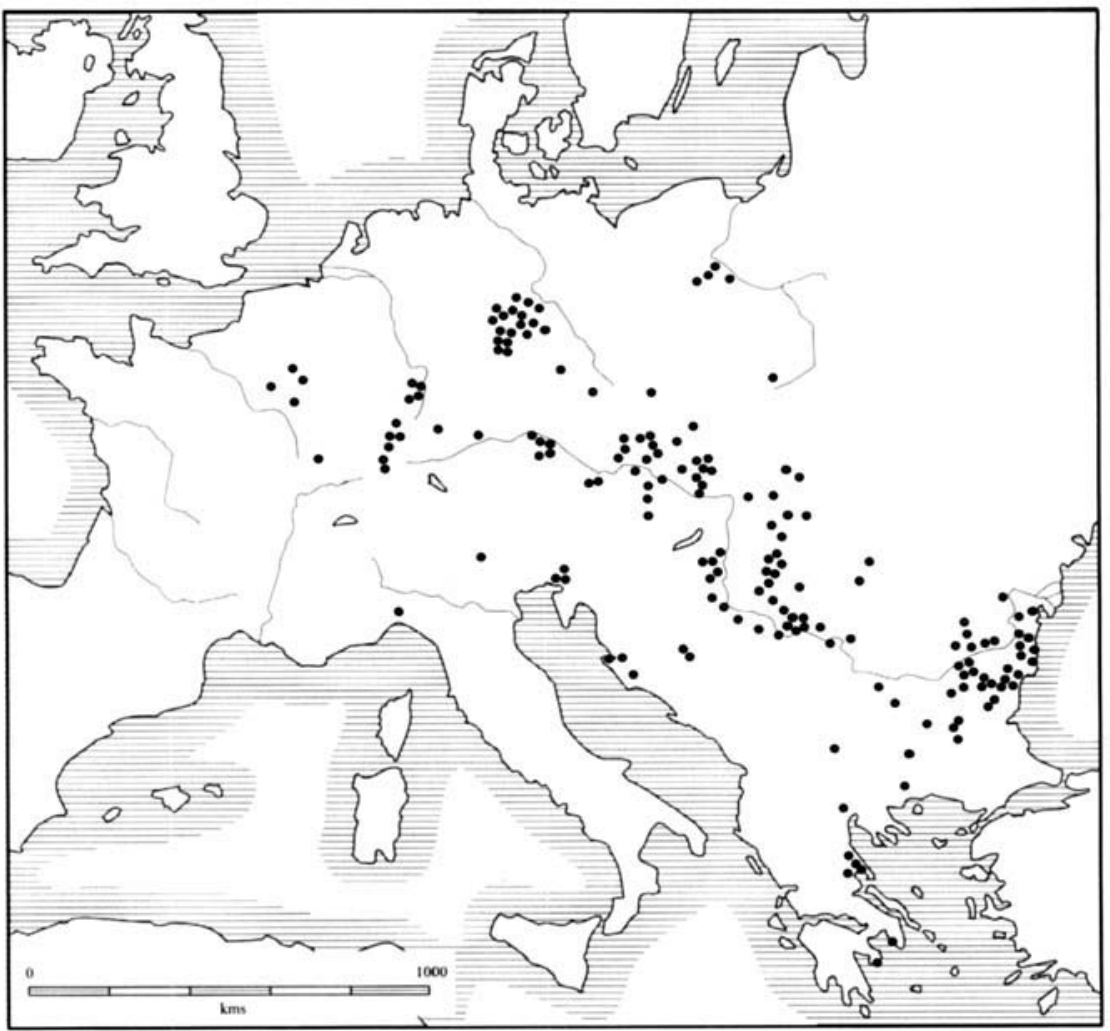

FIGURE 5. The distribution of Spondylus shells in Europe (after Müller 1997).

wards the likely area of origin of the local population. The dead who were buried near-by face in the same direction (FIGURE 2). Is it possible that these orientations were considered propitious because the inhabitants believed themselves to share a common origin?

In fact, the southern and southeastern axis of the long houses is reflected by another archaeological phenomenon which has so far defied explanation. Spondylus shells occur throughout the Linear Pottery Culture but seem to have been imported into central and western Europe from areas much further to the southeast (Müller 1997). Their entire distribution extends from France to the Black Sea (FIGURE 5). They are found in Linearbandkeramik cemeteries, where they occur in the graves of the older members of the community, but they are also recorded in parts of southern Europe which had been settled by farmers during an earlier period. However the movement of these distinctive shells was organized, they provided a tangible link between the newly colonized areas and regions that had been settled many generations before. These artefacts do not seem to have played any practical role. Rather, they provided direct testimony of the beliefs of settled communities whose descendants aligned their houses on the same ancestral homelands.

Such arguments may seem remote from the 'curious circumstance' observed by Childe halfa-century ago (1949: 139), but that is because the settlements of the Linear Pottery Culture are too often considered in isolation from the mortuary monuments that eventually took their place. Settlement sites are studied by one group of archaeologists and long barrows by another, and each brings its own assumptions to the task. This article has attempted to question some of those assumptions, for, if its basic thesis is well founded, the long houses of Neolithic Europe were not only dwellings but monuments in their own right which charted the history of the first farming communities. The forms of these buildings mapped out the lives of the living and recalled the importance of the dead.

Acknowledgements. I am grateful to Margaret Mathews for preparing the illustrations and to two referees for their helpful comments. 
References

BirDWELl-Pheasant, D. \& D. LaWREnCE-Zuñiga (ed.). 1999. House life. Space, place and the family in Europe. Oxford: Berg.

CARSTEN, I. \& S. HuCH-IONES (ed.). 1995. About the house. LéviStrauss and beyond. Cambridge: Cambridge University Press.

Chilue, V.G. 1949. The origin of Neolithic culture in Northern Europe, Antiquity 32: 129-35

COUDART, A. 1998. Architecture et société. L'unité et la variance de la maison danubienne. Paris: Éditions de la Maison des Sciences de l'Homme.

FoKkENS, H. \& N. ROYMANS (ed.]. 1991. Nederzettingen uit de bronstijd en de ijzertijd in de lage landen. Amersfoort: Rijksdienst voor bet Oudheidkundig Bodermonderzoek.

Gerrirtson, F. 1999. The cultural biography of the Irom Age houses and the long-term transformation of settlement patterns in the southern Netherlands, in C. Fabech \& J. Ringtved (ed.), Settlement and landscape: 139-48. Arhus: Jutland Archaeological Society.

HUNTER-ANDERSON, R. 1977. A theoretical approach to the study of house form, in L. Binford (ed.), For theory building in archaeology: 287-315. New York (NY): Academic: Press.

KIND, C.-J. 1989. Ulm-Eggingen. Die Ausgrabungen 1982 bis 1985 in der bandkeramischen Sidelung und der mittelaltichen Wüstung. Stuttgart: Konrad Theiss.

LÜNING, I. 1982. Siedlung und Siedlungschaft in bandkeramischer und rössener Zeit, Offa 39: 9-33.

LÜNING, J., U. KLOOS \& S. AlBERT. 1989. Westliche Nachbarn der bandkeramischen Kultur: La Hoguette und Limburg, Germania 67: 355-420.

Marshall, A. 1981. Environmental adaptation and structural design in axially-pitched long houses from Neolithic Europe, World Archaeology 13: 101-21.

MATrHEUSSER, E. 1991. Die geographische Ausrichtung bandkeramischer Häuser, Studien zur Siedlungsarchäologie 1: $1-49$.
MIDGLeY, M. 1992. TRB Culture. The first farmers of the North European Plain. Edinburgh: Edinburgh University Press.

Modderman, P. 1988. The Linear Pottery Culture: diversity in unity, Berichten van de Rijksdienst voor het Oudheidkundig Bodermonderzoek 38: 63-139.

MORDANT, D. 1997. Le complexe des Réaudins à Balloy: enceinte et nécropole monumentale, in C. Constantin, D Mordant \& D. Simonin (ed.), La Culture de Cerny: 44979. Nemours: L'Association pour la Promotion de la Recherche Archéologique en Ile-de-France.

MÜLLER, J. 1997. Neolithische und chalkolithische SpondylusArtefakte. Anmerkungen zu Verbreitung, Tauschgebiet und sozialer Funktion, in C. Becker et al. (ed.), Beitrage zur prähistorischen Archäologie zwischen Nord- und Südosteuropa. Festschrift für Bernhard Hänsel: 91-106. Espelkamp: Marie Leidorf.

Simonin, D. 1997. Analyse spatiale d'un site d'habitat du Néolithique ancien à Échilleuse (Loiret), in A. Bocquet (ed.), Espaces, physiques, espaces social dans l'analyse interne des sites du Néolithique à l'Age du Fer: 345-68. Paris: Éditions du CNRS.

STÄUBLE, H. \& J. LÜNING. 1999. Phosphatanalysen in bandkeramischen Häusern, Archäologisches Korrespondenzblatt 29: 169-87.

Stevanovic, M. 1997. The age of clay. The social dynamics of house dostruction, Journal of Anthropological Archaeology 16: 334-95.

VEIT, U. 1996. Studien zum Problem der Siedlungbesattung im europäischen Neolithikum. Münster: Waxman.

WATERBOLK, H. 1959. Die bandkeramisches Siedlung von Geleen, Palaeohistoria 6-7: 123-67.

Whitrle, A. 1996. Europe in the Neolithic. Cambridge: Cambridge University Press.

\title{
Land and sea: use of terrestrial mammal bones in coastal hunter-gatherer communities
}

\author{
LISA HODGETTS \& F ARID RAHEMTULLA *
}

Terrestrial mammals are frequently undervalued in interpretations of prehistoric coastal economies where middens are used to examine seasonality and diet. Using case-studies from the Northwest Coast of North America, and from Arctic Norway, a more integrated approach to subsistence and technology is proposed.

Key-words; terrestrial mammals, marine economy, diet, raw materials, bone tools

\section{Introduction}

On archaeological sites of coastal hunter-gatherers, marine taxa often far outnumber terrestrial mammals among the unmodified faunal remains. In such cases, terrestrial mammals are generally deemed unimportant in the overall economy because of their minor contribution to the diet. Such inferences overlook the fact that land mammals also provide numerous other materials including bone and antler, which may have played crucial roles in past economic lifeways. Several lines of evidence indicate the

\footnotetext{
* Note. Authors' contributions are equal. Hodgetts, Archaeology Unit, Queen's College, Memorial University of Newfoundland, St John's NF, A1C 5S7 Canada Ihodgett@mun.ca Rahemtulla, Anthropology Program, University of Northern British Columbia, 3333 University Way, Prince George BC, V2N 4Z9 Canada, farid@unbc.ca
}

Received 31 March 2000, accepted 7 July 2000, revised 8 November 2000. 